
\title{
is Research Suare \\ Functional outcome after surgical treatment of cavernous malformation involving ocular motor cranial nerves: A systematic review
}

\section{Kyoung Su Sung}

Department of Neurosurgery, Dong-A University Hospital, Dong-A University of Medicine Jaejoon Lim

Department of Neurosurgery, Bundang CHA Medical Center, CHA University College of Medicine

\section{So Jung Hwang}

Department of Neurosurgery, Bundang CHA Medical Center, CHA University College of Medicine

\section{Duk-Hee Chun}

Department of Anesthesiology and Pain Medicine, Bundang CHA Medical Center, CHA University College of Medicine

KYUNGGICHO ( $\nabla$ sandori50@gmail.com )

Bundang CHA Medical Center, CHA University College of Medicine https://orcid.org/0000-0001-7855-2719

\section{Research}

Keywords: cavernous malformation, cranial nerve, treatment outcome

Posted Date: March 18th, 2020

DOI: https://doi.org/10.21203/rs.3.rs-17662/v1

License: (a) This work is licensed under a Creative Commons Attribution 4.0 International License. Read Full License

Version of Record: A version of this preprint was published at Journal of Clinical Neuroscience on December 1st, 2020. See the published version at https://doi.org/10.1016/j.jocn.2020.09.036. 


\section{Abstract}

Background: Cavernous malformations (CMs) of cranial nerves (CN) III, IV, and VI are extremely rare, and limited studies have assessed the functional outcomes after treatment. This systematic review investigated the clinical features of $\mathrm{CMs}$ in ocular motor $\mathrm{CNs}$, including treatment results, and compared different surgical methods for functional preservation of ocular motor CNs.

Methods: 'PubMed', 'SCOPUS', 'Web of Science', and 'Google Scholar' databases were searched to identify case reports and studies published between January 1980 and December 2018. This systematic review adhered to the Preferred Reporting Items for Systematic Reviews and Meta-Analyses.

Results: Twenty-seven patients were identified (median age, 46 years; range, 3 months-71 years). CN III was involved in 17 patients (63.0\%), CN IV in 8 (29.6\%), and CN VI in 2 (7.4\%). Treatments included gross total resection (GTR) and nerve transection in 6 patients (22.2\%), GTR and nerve continuity preservation in 7 (25.9\%), subtotal resection (STR) and nerve continuity preservation in 4 (14.8\%), GTR and end-to-end anastomosis in $5(18.5 \%)$, and conservative care in $3(11.1 \%)$, while the treatment method for $2(7.4 \%)$ patients was not described in the literature. In 22 patients who underwent surgical treatment, functional changes included improvement in 9 patients (40.9\%), no change in 10 (45.5\%), and worsening symptoms in $3(13.6 \%)$. Functional preservation was achieved in $12(54.5 \%)$ of the 22 patients; the nerve continuity preservation method conferred significant advantage for functional preservation compared with other surgical methods ( $p$ $=0.004)$.

Conclusion: Functional preservation of ocular motor CNs can be achieved by nerve continuity preservation. Key Words: cavernous malformation; cranial nerve; treatment outcome

\section{Background}

Cavernous malformation (CM) is an angiographically occult vascular malformation with an incidence of $0.3-$ $0.5 \%$ in the general population $[1,2]$. Although rare, CMs may arise from the cranial nerve $(\mathrm{CN})$, and most of cases occur in the CN II and VII/VIII complex [3,4]. CMs of the CNs typically cause dysfunction of the affected $\mathrm{CN}$, either insidiously via mass effect or acutely due to hemorrhage. Mortality related to $\mathrm{CMs}$ of the $\mathrm{CNs}$ rarely occur $[2,3]$. Therefore, functional preservation gains importance during the management of these lesions. CMs of the ocular motor CNs III, IV, and VI are extremely rare and associated with diplopia and strabismus [5]. Not surprisingly, limited studies have examined the functional outcomes of $\mathrm{CM}$ of the ocular motor $\mathrm{CN}$. Recently, we encountered a case of CN III CM in a patient who presented with diplopia and CN III palsy and achieved the functional preservation after surgical treatment. Therefore, in this study, we performed a systematic review of patients with $\mathrm{CMs}$ of the ocular motor $\mathrm{CNs}$ to compare the different surgical methods in terms of posttreatment functional outcome.

\section{Materials And Methods}

We thoroughly reviewed the 'PubMed', 'SCOPUS', 'Web of Science', and 'Google Scholar' databases to identify relevant case reports and studies of CMs of the ocular motor CNs published between January 1980 and December 2018, based on the Preferred Reporting Items for Systematic Reviews and Meta-Analyses (PRISMA) 
guidelines. The algorithm used the terms 'cavernous malformation', 'cavernous angioma', and 'cranial nerve' as the search terms. Previously published case reports and series described in the literature were reviewed. The inclusion criteria were as follows: (1) surgically confirmed CM of CN III, IV, and VI (by histology or intraoperative view), and (2) radiological confirmation of disease. Studies with poorly described case details or lacking a description of individual patient data, and those with surgical or radiological evidence of cavernous hemangioma in the cavernous sinus were excluded.

A total of 26 reported patients were identified from 23 previously published articles. All relevant demographic, clinical, and radiological data were extracted and summarized, along with the year of publication. One patient from our own institution was included in the dataset. The preoperative and postoperative $\mathrm{CN}$ functions were defined as the presence of complete nerve palsy, incomplete nerve deficit and no deficit, according to descriptions in literatures. The treatment methods were defined as follow: 'gross total resection (GTR) and nerve transection,' when the CM was excised simultaneously with the involved portion of the CN portion; 'GTR and nerve continuity preservation,' when the $\mathrm{CM}$ was excised totally with preservation of $\mathrm{CN}$ continuity; 'subtotal resection (STR) and nerve continuity preservation,' when the lesion was not resected totally because of various reasons, with preservation of CN continuity; and 'GTR and end-to-end anastomosis,' when the CM and involved $\mathrm{CN}$ were excised simultaneously and additional procedures (direct anastomosis suture, nerve graft, etc.) were performed for $\mathrm{CN}$ continuity. Based on postoperative function of the $\mathrm{CN}$, functional changes were defined as improved, unchanged, or worsened after comparing with the preoperative $\mathrm{CN}$ function. Functional preservation indicated retention of $\mathrm{CN}$ function after treatment without complete $\mathrm{CN}$ palsy. The patient from our institution provided written informed consent for the inclusion of his data in this study.

\section{Statistical Analyses}

Comparison of categorical variables in each group, such as treatment methods, functional change, and functional preservation was performed with Fisher's exact test. All statistical analyses were performed with $\mathrm{R}$ studio version 1.1.456 (RStudio, Inc., Boston, MA, http://www.rstudio.com/), and p values $<0.05$ was considered statistically significant.

\section{Results}

The initial database search identified 1938 articles of which 23 (26 individual patient cases) were included in the final analysis (Fig. 1). This study included 27 patients (18 men, 9 women) with CMs of the ocular motor CNs. The clinical characteristics of the patients are summarized in Table 1 [2-4, 6-24]. Their median age was 46 years (range, 3 months-71 years). Left and right side CNs were affected in the ratio of 13:13. CM involved CN III in 17 (63.0\%), CN VI in 2 (7.4\%), and CN IV in 8 (29.6\%) patients. Assessment of pre-treatment CN function showed complete palsy in $15(55.6 \%)$, an incomplete deficit in $6(22.2 \%)$, and no deficit in $4(14.8 \%)$ patients, while it was not described in $2(7.4 \%)$ patients. After treatment, complete palsy occurred in 10 (37.0\%), an incomplete deficit in 10 (37.0\%), and no deficit in 5 (17.4\%) patients, while the outcome was not described in $2(7.4 \%)$ patients. Treatment methods used were GTR and nerve transection in $6(22.2 \%)$, GTR and nerve continuity preservation in 7 (25.9\%), STR and nerve continuity preservation in 4 (14.8\%), GTR and end-toend anastomosis in 5 (18.5\%), and conservative care in $3(11.1 \%)$ patients. Among the 22 patients who 
underwent surgery, functional changes revealed improvement in 9 (40.9\%), no change in 10 (45.5\%), and worsening function in $3(13.6 \%)$ patients. Functional preservation was achieved in 12 (54.5\%) of 22 patients. There was no disease-related mortality. 
Table 1

Literature review of cavernous malformation affecting ocular motor cranial nerves

\begin{tabular}{|c|c|c|c|c|c|c|c|c|}
\hline \multirow{2}{*}{$\begin{array}{l}\text { Author \& } \\
\text { year }\end{array}$} & \multirow[t]{2}{*}{ CN } & \multirow[t]{2}{*}{ S/A } & \multirow[t]{2}{*}{ Side } & \multirow[t]{2}{*}{ Treatment } & \multicolumn{2}{|c|}{ Nerve function } & \multirow{2}{*}{$\begin{array}{l}\text { Functional } \\
\text { change }\end{array}$} & \multirow{2}{*}{$\begin{array}{l}\text { Functional } \\
\text { preservation }\end{array}$} \\
\hline & & & & & Pre-Tx & Post-Tx & & \\
\hline $\begin{array}{l}\text { Blizzard et } \\
\text { al. \& } 2018 \\
\text { [28] }\end{array}$ & III & M/3mon & $\mathrm{Lt}$ & $\begin{array}{l}\text { Conservative } \\
\text { care }\end{array}$ & Incom & $\begin{array}{l}\text { Improved } \\
\text { Incom }\end{array}$ & Improved & Yes \\
\hline $\begin{array}{l}\text { Díaz et al. } \\
\& 2010 \text { [7] }\end{array}$ & III & $\mathrm{M} / 46$ & $\mathrm{Lt}$ & $\begin{array}{l}\text { GTR \& n. } \\
\text { continuity } \\
\text { preservation }\end{array}$ & Incom & $\begin{array}{l}\text { No } \\
\text { deficit }\end{array}$ & Improved & Yes \\
\hline $\begin{array}{l}\text { Inui et al. } \\
\& 2016 \text { [9] }\end{array}$ & III & $M / 51$ & Rt & $\begin{array}{l}\text { GTR \& n. } \\
\text { continuity } \\
\text { preservation }\end{array}$ & Com & Incom & Improved & Yes \\
\hline $\begin{array}{l}\text { Itshayek et } \\
\text { al. \& } 2007 \\
\text { [10] }\end{array}$ & III & $F / 25$ & Rt & $\begin{array}{l}\text { Exploration } \\
\text { (no } \\
\text { resection) }\end{array}$ & $\begin{array}{l}\text { No } \\
\text { deficit }\end{array}$ & $\begin{array}{l}\text { No } \\
\text { deficit }\end{array}$ & Unchanged & Yes \\
\hline $\begin{array}{l}\text { Lombardi } \\
\text { et al. \& } \\
1994 \text { [12] }\end{array}$ & III & $F / 46$ & $\mathrm{Lt}$ & $\begin{array}{l}\text { GTR \& n. } \\
\text { continuity } \\
\text { preservation }\end{array}$ & Com & Incom & Improved & Yes \\
\hline $\begin{array}{l}\text { Matias- } \\
\text { Guiu et al. } \\
\& 1990 \\
{[13]}\end{array}$ & III & $F / 36$ & $\mathrm{Lt}$ & $\begin{array}{l}\text { STR \& n. } \\
\text { continuity } \\
\text { preservation }\end{array}$ & $\begin{array}{l}\text { No } \\
\text { deficit }\end{array}$ & Incom & Worsened & Yes \\
\hline $\begin{array}{l}\text { Muzumdar } \\
\text { et al. \& } \\
2001 \text { [17] }\end{array}$ & III & $M / 45$ & $\mathrm{Lt}$ & $\begin{array}{l}\text { GTR \& n. } \\
\text { continuity } \\
\text { preservation }\end{array}$ & Incom & $\begin{array}{l}\text { Improved } \\
\text { Incom }\end{array}$ & Improved & Yes \\
\hline $\begin{array}{l}\text { Obaid et } \\
\text { al. \& } 2014 \\
\text { [4] }\end{array}$ & III & $\mathrm{M} / 71$ & $\mathrm{Lt}$ & $\begin{array}{l}\text { GTR \& n. } \\
\text { continuity } \\
\text { preservation }\end{array}$ & Com & Com & Unchanged & No \\
\hline $\begin{array}{l}\text { Ogilvy et } \\
\text { al. \& } 1993 \\
\text { [16] }\end{array}$ & III & $M / 25$ & Rt & $\begin{array}{l}\text { GTR \& } \mathrm{n} \text {. } \\
\text { transection }\end{array}$ & Com & Com & Unchanged & No \\
\hline $\begin{array}{l}\text { Park et al. } \\
\& 2005 \\
{[17]}\end{array}$ & III & $M / 33$ & $\mathrm{Lt}$ & $\begin{array}{l}\text { STR \& n. } \\
\text { continuity } \\
\text { preservation }\end{array}$ & Incom & $\begin{array}{l}\text { Improved } \\
\text { Incom }\end{array}$ & Improved & Yes \\
\hline $\begin{array}{l}\text { Patro et al. } \\
\& 2008 \\
{[18]}\end{array}$ & III & $M / 54$ & Rt & $\begin{array}{l}\text { Conservative } \\
\text { care }\end{array}$ & Com & Incom & Improved & Yes \\
\hline $\begin{array}{l}\text { Rotondo et } \\
\text { al. \& } 2014 \\
\text { [2] }\end{array}$ & III & $F / 34$ & Rt & $\begin{array}{l}\text { GTR \& n. } \\
\text { continuity } \\
\text { preservation }\end{array}$ & Incom & $\begin{array}{l}\text { Improved } \\
\text { Incom }\end{array}$ & Improved & Yes \\
\hline
\end{tabular}

CN cranial nerve, GTR gross total resection, STR subtotal resection, Incom incomplete nerve deficit, Com complete nerve palsy, ND not described, $n$. nerve, S/A sex/age in years (unless specified), M male, F female, Rt right, Lt left, Tx treatment. 


\begin{tabular}{|c|c|c|c|c|c|c|c|c|}
\hline \multirow{2}{*}{$\begin{array}{l}\text { Author \& } \\
\text { year }\end{array}$} & \multirow[t]{2}{*}{$\mathrm{CN}$} & \multirow[t]{2}{*}{ S/A } & \multirow[t]{2}{*}{ Side } & \multirow[t]{2}{*}{ Treatment } & \multicolumn{2}{|c|}{ Nerve function } & \multirow{2}{*}{$\begin{array}{l}\text { Functional } \\
\text { change }\end{array}$} & \multirow{2}{*}{$\begin{array}{l}\text { Functional } \\
\text { preservation }\end{array}$} \\
\hline & & & & & Pre-Tx & Post-Tx & & \\
\hline $\begin{array}{l}\text { Scott \& } \\
1983 \text { [19] }\end{array}$ & III & $\mathrm{M} / 14$ & Rt & $\begin{array}{l}\text { GTR \& n. } \\
\text { transection }\end{array}$ & Com & Com & Unchanged & No \\
\hline $\begin{array}{l}\text { Wolfe et } \\
\text { al. \& } 2011 \\
\text { [22] }\end{array}$ & III & $M / 26$ & Rt & $\begin{array}{l}\text { STR \& n. } \\
\text { continuity } \\
\text { preservation }\end{array}$ & Com & $\begin{array}{l}\text { No } \\
\text { deficit }\end{array}$ & Improved & Yes \\
\hline $\begin{array}{l}\text { Wolfe et } \\
\text { al. \& } 2011 \\
\text { [22] }\end{array}$ & III & $F / 69$ & $\mathrm{Lt}$ & $\begin{array}{l}\text { GTR \& n. } \\
\text { continuity } \\
\text { preservation }\end{array}$ & Com & Com & Unchanged & No \\
\hline $\begin{array}{l}\text { Yamada et } \\
\text { al. \& } 1986 \\
\text { [24] }\end{array}$ & III & M/33 & $\mathrm{Lt}$ & $\begin{array}{l}\text { GTR \& n. } \\
\text { transection }\end{array}$ & Com & Com & Unchanged & No \\
\hline $\begin{array}{l}\text { Present } \\
\text { patient \& } \\
2019\end{array}$ & III & $\mathrm{M} / 43$ & Rt & $\begin{array}{l}\text { STR \& n. } \\
\text { continuity } \\
\text { preservation }\end{array}$ & Com & Incom & Improved & Yes \\
\hline $\begin{array}{l}\text { Díaz et al. } \\
\text { \& } 2010 \text { [7] }\end{array}$ & VI & $M / 56$ & ND & ND & ND & ND & Improved & Yes \\
\hline $\begin{array}{l}\text { Moon et } \\
\text { al. \& } 2011 \\
{[14]}\end{array}$ & VI & $F / 54$ & Rt & $\begin{array}{l}\text { GTR \& n. } \\
\text { transection }\end{array}$ & Incom & Com & Worsened & No \\
\hline $\begin{array}{l}\text { Bassetti et } \\
\text { al. \& } 1994 \\
\text { [6] }\end{array}$ & IV & $\mathrm{F} / 50$ & $\mathrm{Lt}$ & $\begin{array}{l}\text { GTR \& end } \\
\text { to end } \\
\text { anastomosis } \\
\text { (and/or } n \text {. } \\
\text { graft) }\end{array}$ & Com & Com & Unchanged & No \\
\hline $\begin{array}{l}\text { Graffeo et } \\
\text { al. \& } 2017 \\
\text { [8] }\end{array}$ & IV & $M / 57$ & L & $\begin{array}{l}\text { GTR \& n. } \\
\text { transection }\end{array}$ & Com & Com & Unchanged & No \\
\hline $\begin{array}{l}\text { Kraschl et } \\
\text { al. \& } 2014 \\
\text { [11] }\end{array}$ & IV & $\mathrm{M} / 70$ & Rt & $\begin{array}{l}\text { GTR \& end } \\
\text { to end } \\
\text { anastomosis } \\
\text { (and/or n. } \\
\text { graft) }\end{array}$ & Com & Incom & Improved & Yes \\
\hline $\begin{array}{l}\text { Lombardi } \\
\text { et al. \& } \\
1994 \text { [12] }\end{array}$ & IV & $\mathrm{F} / 50$ & Rt & $\begin{array}{l}\text { GTR \& end } \\
\text { to end } \\
\text { anastomosis } \\
\text { (and/or n. } \\
\text { graft) }\end{array}$ & Com & Com & Unchanged & No \\
\hline $\begin{array}{l}\text { Manjila et } \\
\text { al. \& } 2011 \\
\text { [3] }\end{array}$ & IV & $F / 31$ & $\mathrm{Lt}$ & $\begin{array}{l}\text { GTR \& n. } \\
\text { transection }\end{array}$ & $\begin{array}{l}\text { No } \\
\text { deficit }\end{array}$ & Com & Worsened & No \\
\hline
\end{tabular}

CN cranial nerve, GTR gross total resection, STR subtotal resection, Incom incomplete nerve deficit, Com complete nerve palsy, ND not described, $n$. nerve, S/A sex/age in years (unless specified), M male, F female, Rt right, Lt left, Tx treatment. 


\begin{tabular}{|c|c|c|c|c|c|c|c|c|}
\hline \multirow{2}{*}{$\begin{array}{l}\text { Author \& } \\
\text { year }\end{array}$} & \multirow[t]{2}{*}{ CN } & \multirow[t]{2}{*}{ S/A } & \multirow[t]{2}{*}{ Side } & \multirow[t]{2}{*}{ Treatment } & \multicolumn{2}{|c|}{ Nerve function } & \multirow{2}{*}{$\begin{array}{l}\text { Functional } \\
\text { change }\end{array}$} & \multirow{2}{*}{$\begin{array}{l}\text { Functional } \\
\text { preservation }\end{array}$} \\
\hline & & & & & Pre-Tx & Post-Tx & & \\
\hline $\begin{array}{l}\text { Sindou et } \\
\text { al. \& } 1992 \\
\text { [20] }\end{array}$ & IV & $M / 65$ & Rt & $\begin{array}{l}\text { GTR \& end } \\
\text { to end } \\
\text { anastomosis } \\
\text { (and/or n. } \\
\text { graft) }\end{array}$ & $\begin{array}{l}\text { No } \\
\text { deficit }\end{array}$ & $\begin{array}{l}\text { No } \\
\text { deficit }\end{array}$ & Unchanged & Yes \\
\hline $\begin{array}{l}\text { Sürücü et } \\
\text { al. \& 2007 } \\
\text { [21] }\end{array}$ & IV & $M / 53$ & Lt & $\begin{array}{l}\text { GTR \& end } \\
\text { to end } \\
\text { anastomosis } \\
\text { (and/or } n . \\
\text { graft) }\end{array}$ & Com & $\begin{array}{l}\text { No } \\
\text { deficit }\end{array}$ & Improved & Yes \\
\hline $\begin{array}{l}\text { Yaghi et } \\
\text { al. \& } 2011 \\
\text { [23] }\end{array}$ & IV & $\mathrm{M} / 70$ & $\mathrm{Lt}$ & ND & ND & ND & ND & ND \\
\hline $\begin{array}{l}\mathrm{CN} \text { cranial } \\
\text { complete } \mathrm{n} \\
\text { Rt right, Lt I }\end{array}$ & $\mathrm{p}$ & $\begin{array}{l}\text { gros } \\
\text { ND n } \\
\text { atmen }\end{array}$ & $\begin{array}{l}\text { resec } \\
\text { cribec }\end{array}$ & $\begin{array}{l}\text { on, STR subto } \\
\text { ר. nerve, S/A s }\end{array}$ & $\begin{array}{l}\text { resecti } \\
\text { /age in }\end{array}$ & $\begin{array}{l}\text { Incom i } \\
\text { ars (unl }\end{array}$ & $\begin{array}{l}\text { רplete nerve } \\
\text { pecified), M }\end{array}$ & $\begin{array}{l}\text { eficit, Com } \\
\text { ale, F female }\end{array}$ \\
\hline
\end{tabular}

We evaluated 22 patients who underwent surgery to identify the appropriate surgical method associated with postoperative functional change and CN function preservation (Table 2). GTR or STR and nerve continuity preservation showed a better result for postoperative functional improvement than other surgical treatment methods with a statistical significance $(p=0.008)$. GTR and nerve transection did not achieve improvement. Moreover, GTR or STR and nerve continuity preservation method showed a significant advantage over other surgical methods for functional preservation $(p=0.004)$.

Table 2

Functional outcomes after surgical treatment for cavernous malformation of ocular motor cranial nerves $(\mathrm{n}=$ 22)

\begin{tabular}{|lllll|}
\hline Nerve function & $\begin{array}{l}\text { GTR/STR \& nerve continuity } \\
\text { preservation }(n=11)\end{array}$ & $\begin{array}{l}\text { GTR \& } \\
\text { anastomosis } \\
(\mathbf{n}=5)\end{array}$ & $\begin{array}{l}\text { GTR \& nerve } \\
\text { transection }(\mathbf{n}=\mathbf{6})\end{array}$ & $\begin{array}{l}\text { p- } \\
\text { value* }\end{array}$ \\
\hline $\begin{array}{l}\text { Improved: } \\
\begin{array}{l}\text { Unchanged: } \\
\text { Worsened }\end{array}\end{array}$ & 8: $2: 1$ & $1: 4: 0$ & $0: 4: 2$ & 0.008 \\
\hline $\begin{array}{l}\text { Functional } \\
\text { preservation (Yes: }\end{array}$ & $9: 2$ & $3: 2$ & $0: 6$ & 0.004 \\
\hline No) & & & & \\
\hline GTR gross total resection, STR subtotal resection & & & \\
\hline * Fisher' exact test was used for this analysis & & & \\
\hline
\end{tabular}

\section{Concise case report}


Video clip

We included a 43-year-old man from our institute in the above analysis. He experienced progressive ptosis and diplopia in the right eye for 1 month before admission. The patient was diagnosed with complete CN III palsy during an initial neurologic examination. A T1-weighted contrast-enhanced magnetic resonance image (MRI) showed a solid gadolinium-enhanced mass in the right-sided ambient and crural cisternal spaces. The mass had a hemorrhagic center (Fig. 2A, B). A prompt surgery was performed using the modified lateral supraorbital approach [25]. The soft, hypervascular mass was observed to be connected with CN III (Fig. 2C). Subsequently, a large portion of the main mass was resected; however, the small residual lesion continued to maintain connectivity with CN III (Fig. 3A, B, C). Pathologic diagnosis confirmed a case of CM (Fig. 3D). The presurgical neurological deficit persisted postoperatively. Postoperative brain MRI showed a small remnant mass (Fig. 3E, F). The patient's CN III palsy improved gradually 3 months after the surgery.

\section{Discussions}

Ocular motor CNs III, IV, and VI supply motor fibers to the extraocular eye muscles [5]. Although CMs of the ocular motor $\mathrm{CNs}$ are extremely rare, these lesions result in stable or progressive isolated $\mathrm{CN}$ deficits, such as diplopia and strabismus $[1,3,22]$. Because CMs are occult vascular lesions, some patients develop subarachnoid hemorrhage (SAH), although they are not as severe as an aneurysmal SAH [23, 26]. In our study, there was no disease-related mortality; however, all patients experienced diplopia and strabismus, which impaired their quality of life. Therefore, functional preservation is vital in the surgical management of patients with CMs involving the ocular motor CNs. Surgical resection without any postoperative neurological deficit for treating patients with $\mathrm{CMs}$ is debatable, and other factors such as clinical presentation, degree of CM adhesion to the CNs, and history of bleeding should be considered [1, 10]. However, this study focused on the surgical methodology based on its ability to preserve and/or improve $\mathrm{CN}$ function.

Presently, CMs are easily detected with gradient-echo and T2-susceptibility weighted MRI sequences [1, 2, 11]. Treatment of CM involving the ocular motor CNs is based on MRI findings. For cases with suspicious MRI findings and progressive, isolated CN deficits, the physician must perform prompt surgical treatment. In our study, some patients, including our patient, were promptly treated with CM resection and preservation of nerve continuity, and they showed recovery of the CN function $[2,12,15,22]$.

Previously, GTR and nerve transection were owing to the risk of re-bleeding from the remnant lesion, and assuming that patients with complete $\mathrm{CN}$ palsy did not have the possibility of recovery $[16,19,24]$. Scott et al. regretted their decision to transect the nerve for removing CMs [27]. In our review, all patients who underwent nerve transection experienced complete CN palsy postoperatively, and had persistent diplopia, strabismus, and/or ptosis $[3,14,16,19,24]$. GTR and end-to-end anastomosis were performed only for cases of CMs of CN IV $[6,11,12,20,21]$. Among the five patients who underwent these procedures, diplopia and strabismus resolved postoperatively in the three patients [11, 20,21]. However, end-to-end anastomosis is not always possible during surgery because of anatomical and technical challenges. For these reasons, anastomosis was not performed for any patient with CMs involving CN III and VI. Moreover, the exact reason for the improvement in patients' symptoms after an anastomosis remains to be identified. Whether this improvement is due to 
Wallerian degeneration occurring in the thinnest CN IV or because of the patients' adaptation based on specific characteristics of CN IV palsy is debated in the literature [11, 20, 21].

Surgical resection was the primary treatment modality in our study, whereas three patients were treated conservatively $[10,18,28]$. Itshayek et al. reported that no neurologic deficits occurred postoperatively for 18 months after a craniotomy and exploration of the interpeduncular cistern in their patient who did not have any $\mathrm{CN}$ deficit [10]. A 3-month-old baby with non-progressive neurologic deficit was managed conservatively because of high surgical risk; nevertheless, the patient showed signs of recovery [28]. Symptom progression due to CMs of the ocular motor $\mathrm{CNs}$ is also associated with repeated intralesional hemorrhage. Progressive worsening of $\mathrm{CN}$ deficits could be an indication for surgical treatment of CMs. Aggressive surgical intervention could cause new deficits due to the manipulation of ocular motor CNs in patients with stable symptoms. Thus, surgery must be carefully considered as a preventive therapy for patients with asymptomatic lesions.

An understanding of the natural history of the disease aids with the treatment strategy. For general CMs, the annual rate of hemorrhage is $0.6 \%$ in patients without prior hemorrhage and $4.5 \%$ in patients with prior hemorrhage [29]. Other studies have reported that the hemorrhagic rates vary from $0.25-3.1 \%$ per patient-year [22], or that the annual bleeding rate of patients can be $0.25 \%-20 \%$ regardless of the lesion location in the brain [2]. In our study, although the exact rate of hemorrhage could not be elucidated, no patient had reported rebleeding after STR and conservative care. Advanced imaging techniques facilitate the radiological diagnosis of these lesions and could aid in a better understanding of the natural history of CMs of ocular motor CNs.

In our study, the most appropriate surgical treatment for functional preservation was nerve continuity preservation. CMs are not only adhesive but can also invade the neural tissue of the CNs [20, 21]. Irrespective of the severity of involvement, CMs are not fatal and are not associated with mortality, even when resected partially such as in STR. The CN deficits are mainly attributable to the mass effect of the CM and irritation from re-bleeding $[2,3]$. Relieving the mass effect in itself can recover part or complete CN function. Therefore, the primary surgical principle should focus on preserving nerve continuity. Some authors have reported that STR has the risk of recurrent bleeds $[1,2,16]$; however, no patient examined experienced recurrent bleeding after STR in our study. Of course, GTR with nerve continuity preservation is the ideal standard of care, but it is not always possible. The CMs are contained within a pseudocapsule, and therefore, performing a minimal resection of hemosiderin-stained tissue and traction of $\mathrm{CN}$ with sharp dissection is important for preserving nerve continuity and function of the ocular motor CNs during surgical treatment of CMs $[1,12,14,17]$.

Our study had some limitations, which hindered the better characterization of the treatment methods for CMs of the ocular motor CNs. First, it was difficult to investigate the role of extent of resection on the functional outcome and re-bleeding after treatment because the existing literature is limited to small numbers and isolated case reports. Therefore, we focused on the role of nerve continuity preservation during surgery rather than the extent of resection. Second, the appropriate follow-up period after treatment could not be identified in our study because most reports did not present the follow-up period. However, CMs are not malignant; therefore, further study should assess the natural course of the disease, including cases of re-bleeding.

\section{Conclusions}


Based on the systematic review, we recommended surgical treatment for patients with progressive deficits due to $\mathrm{CMs}$ involving the ocular motor CNs. A prompt surgery must aim to achieve nerve continuity preservation for functional recovery and preservation of ocular motor CNs.

\section{Abbreviations}

CM: Cavernous malformation, CN: Cranial nerve, GTR: Gross total resection, MRI: Magnetic resonance image, PRISMA: Preferred Reporting Items for Systematic Reviews and Meta-Analyses, SAH: Subarachnoid hemorrhage, STR: Subtotal resection

\section{Declarations}

\section{Ethics approval and consent to participate}

The Bundang CHA Hospital Institutional Review Board approval was obtained for this study, and all patients signed informed consent forms.

\section{Consent for publication}

The data was analyzed retrospectively after obtaining informed consent from the patient who was included from our institute.

\section{Competing interests}

The authors declare that they have no competing interests.

\section{Availability of data and materials}

Data sharing is not applicable to this article as no datasets were generated.

\section{Funding}

This research was supported by grants of the Industrial Technology Innovation Program through the Ministry of Trade, Industry and Energy (Korea), funded by the Ministry of Trade, Industry and Energy, Republic of Korea (Grant No. 10067378) and Basic Science Research Program through the National Research Foundation of Korea (NRF), funded by the Korea Government (MSIT) (Grant No. 2018R1C1B5086460)

Author contributions: Conception and design, acquisition of data, analysis and interpretation of data, statistical analysis, Kyoung Su Sung, Jaejoon Lim; drafting the article, Kyoung Su Sung; critically revising the article, Jaejoon Lim; approved the final version of the manuscript, Kyoung Su Sung, Jaejoon Lim, So Jung Hwang, Duk-Hee Chun and Kyung Gi Cho; administrative/technical/material support, study supervision, DukHee Chun and Kyung Gi Cho

\section{Authors' information}

Kyoung Su Sung and Jaejoon Lim joint first authors. 
Acknowledgement

Not applicable

\section{References}

1. Deshmukh VR, Albuquerque FC, Zabramski JM, Spetzler RF. Surgical management of cavernous malformations involving the cranial nerves. Neurosurgery 2003;53:352-357; discussion 357

2. Rotondo M, Natale M, D'Avanzo R, Pascale M, Scuotto A. Cavernous malformations isolated from cranial nerves: unexpected diagnosis? Clin Neurol Neurosurg 2014;126:162-168

3. Manjila S, Moon K, Weiner MA, Cohen ML, Leigh RJ, Megerian CA, Bambakidis NC. Cavernous malformation of the trochlear nerve: case report and review of the literature on cranial nerve cavernomas. Neurosurgery 2011;69:E230-238; discussion E238

4. Obaid S, Li S, Denis D, Weil AG, Bojanowski MW. Resection of an oculomotor nerve cavernous angioma. Surg Neurol Int 2014;5:S203-S207

5. Adams ME, Linn J, Yousry I. Pathology of the ocular motor nerves III, IV, and VI. Neuroimaging Clin N Am 2008;18:261-282

6. Bassetti C, Tribolet $\mathrm{N}$ de, Deruaz JP, Regli F. Arteriovenous malformation of the trochlear nerve: a rare cause of acquired isolated fourth nerve palsy. Neuroophthalmology 1994;14:135-139

7. Díaz CA, Zottis GC, Rehder R, Borba LAB. Cavernous angiomas of the cranial nerves: surgical management, results, and complications. Rev Mex Neuroci 2010;11:258-268

8. Graffeo CS, Copeland WR, Mukunyadzi P, Krisht AF. Synchronous ipsilateral cavernous malformations of the trochlear nerve. J Clin Neurosci 2017;40:59-62

9. Inui T, Hashimoto H, Fujimoto K, Shimokawara T, Nishiguchi M, Yokoyama S, Omoto K, Matsuoka R, Yaegaki T. A case of extra-axial cavernous angioma originating from the oculomotor nerve. Indian $\mathrm{J}$ Neurosurg 2016;05(02):133-135

10. Itshayek E, Perez-Sanchez X, Cohen JE, Umansky F, Spektor S. Cavernous hemangioma of the third cranial nerve: case report. Neurosurgery 2007;61:E653; discussion E653

11. Kraschl J, Spendel MC, Kiefer A, Kau T, Grossauer S, Vince GH. Cavernous haemangioma of the trochlear nerve: case report and review of the literature. Clin Neurol Neurosurg 2014;125:65-68

12. Lombardi D, Giovanelli M, de Tribolet N. Sellar and parasellar extra-axial cavernous hemangiomas. Acta Neurochir (Wien) 1994;130:47-54

13. Matias-Guiu X, Alejo M, Sole T, Ferrer I, Noboa R, Bartumeus F. Cavernous angiomas of the cranial nerves. report of two cases. J Neurosurg 1990;73:620-622

14. Moon KS, Jung S, Lee KH, Lee MC. Cavernous hemangioma of the abducens nerve: clinical implication of duplicated variants: case report. Neurosurgery 2011;69:E756-760; discussion E760

15. Muzumdar DP, Bhatjiwale MG, Goel A, Doshi P. Cavernous haemangioma in the interpeduncular cistern: case report and review of literature. J Postgrad Med 2001;47:191-193

16. Ogilvy CS, Pakzaban P, Lee JM. Oculomotor nerve cavernous angioma in a patient with Roberts syndrome. Surg Neurol 1993;40:39-42 
17. Park DM, Kim DH. Cavernous angioma of the oculomotor nerve. J Korean Neurosurg Soc 2005;38:147150

18. Patro S, Kesavadas C, Kapilamoorthy TR Right third nerve palsy caused by extra-axial cavernoma in a patient with multiple intracranial cavernomas. Neuroradiol J 2008;21:192-195

19. Scott R. Third nerve palsy in a 14-year old boy due to cavernous angioma of the third nerve.In: Raimondi $A$ (ed) Concepts in Pediatric Neurosurgery, Karger, New York, 1983, pp 100-107

20. Sindou M, Gilg A, Vighetto A, Jouvet A. Cryptic angioma in the trochlear nerve. Excision of the invaded portion and successful repair with an autologous graft: case report. Neurosurgery 1992;30:255-258

21. Sürücü O, Sure U, Mittelbronn M, Meyermann R, Becker R Cavernoma of the trochlear nerve. Clin Neurol Neurosurg 2007;109:791-793

22. Wolfe SQ, Manzano G, Langer DJ, Morcos JJ. Cavernous malformation of the oculomotor nerve mimicking a partially thrombosed posterior communicating artery aneurysm: report of two cases. Neurosurgery 2011;69:E470-474

23. Yaghi S, Oomman S, Keyrouz SG. Non-aneurysmal perimesencephalic subarachnoid hemorrhage caused by a cavernous angioma. Neurocrit Care 2011;14:84-85

24. Yamada T, Nishio S, Matsunaga M, Fukui M, Takeshita I. Cavernous haemangioma in the oculomotor nerve. a case report. J Neurol 1986;233:63-64

25. Lim J, Cho K. The modified lateral supraorbital approach for tumors of the petroclival junction extending into the anterior cerebellopontine area. J Neurooncol 2016;127:541-550

26. Gonzalez LF, Lekovic GP, Eschbacher J, Coons S, Porter RW, Spetzler RF. Are cavernous sinus hemangiomas and cavernous malformations different entities? Neurosurg Focus 2006;21(1):e6

27. Scott RM. Oculomotor nerve cavernous angioma in a patient with Robert's syndrome. Surg Neurol 1994;41:352

28. Blizzard ST, Collins ME, Miller NR Acute transient oculomotor nerve palsy from presumed cavernous angioma in an infant. Neuroophthalmology 2018;42:229-232

29. Kondziolka D, Lunsford LD, Kestle JR. The natural history of cerebral cavernous malformations. J Neurosurg 1995;83:820-824

\section{Figures}


Records identified through database searching $(\mathrm{n}=1938)$
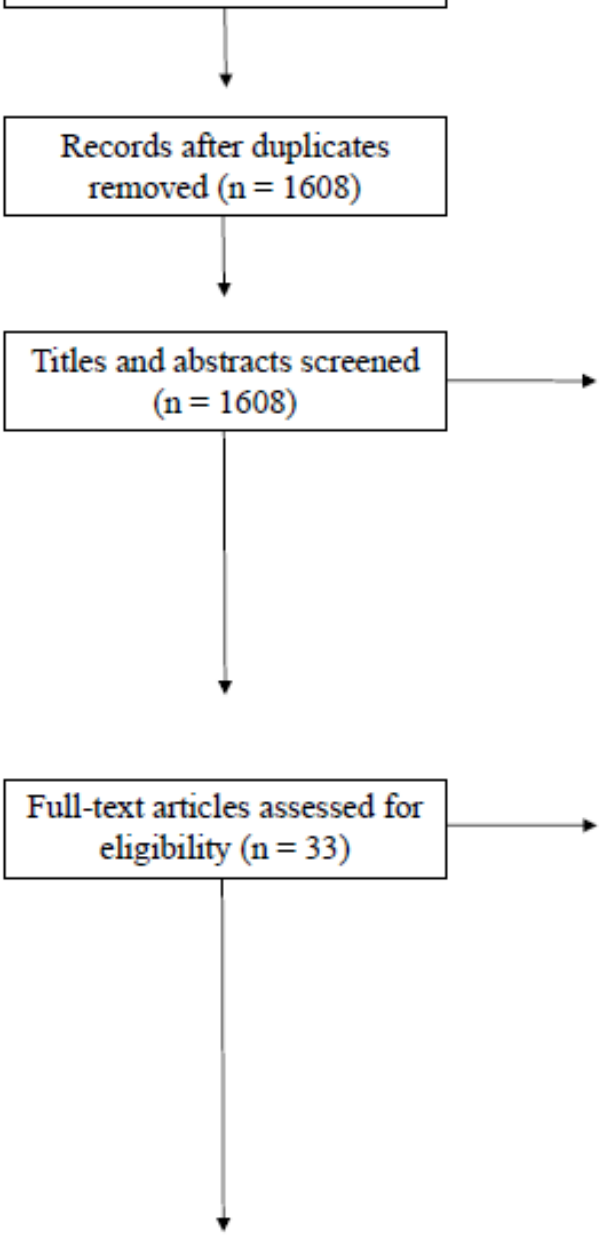

Patients data from 23 eligible articles assessed for inclusion $(\mathrm{n}=34)$

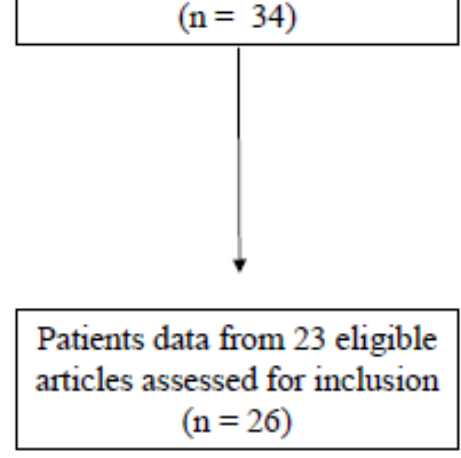

Duplicates removed $(\mathrm{n}=330)$

Records excluded $(\mathrm{n}=1575)$

Reasons:

Irrelevant tiles or abstracts $(n=112)$

Conference abstracts $(n=43)$

Book, general description $(n=203)$

Lacking of description of individual data $(n=482)$

Intraparenchymal lesion $(\mathrm{n}=263)$

Not intracranial lesion $(n=174)$

Intracranial extradural lesion

( $\mathrm{n}=153$ )

Editor's comment $(\mathrm{n}=26)$

Other cranial nerve lesion

$(\mathrm{n}=119)$

\section{Reasons: \\ Brainstem lesion $(n=4)$ \\ Intracranial extradural lesion $(\mathrm{n}=1)$ \\ Other disease entity $(n=2)$ \\ Other cranial nerve lesion \\ $(\mathrm{n}=3)$}

\begin{tabular}{|l|}
\hline \multicolumn{1}{|c|}{ Patients excluded $(\mathrm{n}=8)$} \\
Reasons: \\
Cranial nerve II $(\mathrm{n}=3)$ \\
Cranial nerve V $(\mathrm{n}=1)$ \\
Cranial nerve VII, VIII $(\mathrm{n}=2)$ \\
Cavernous sinus lesion $(\mathrm{n}=3)$ \\
\hline
\end{tabular}

\section{Figure 1}

PRISMA diagram describing the cases selection process. 


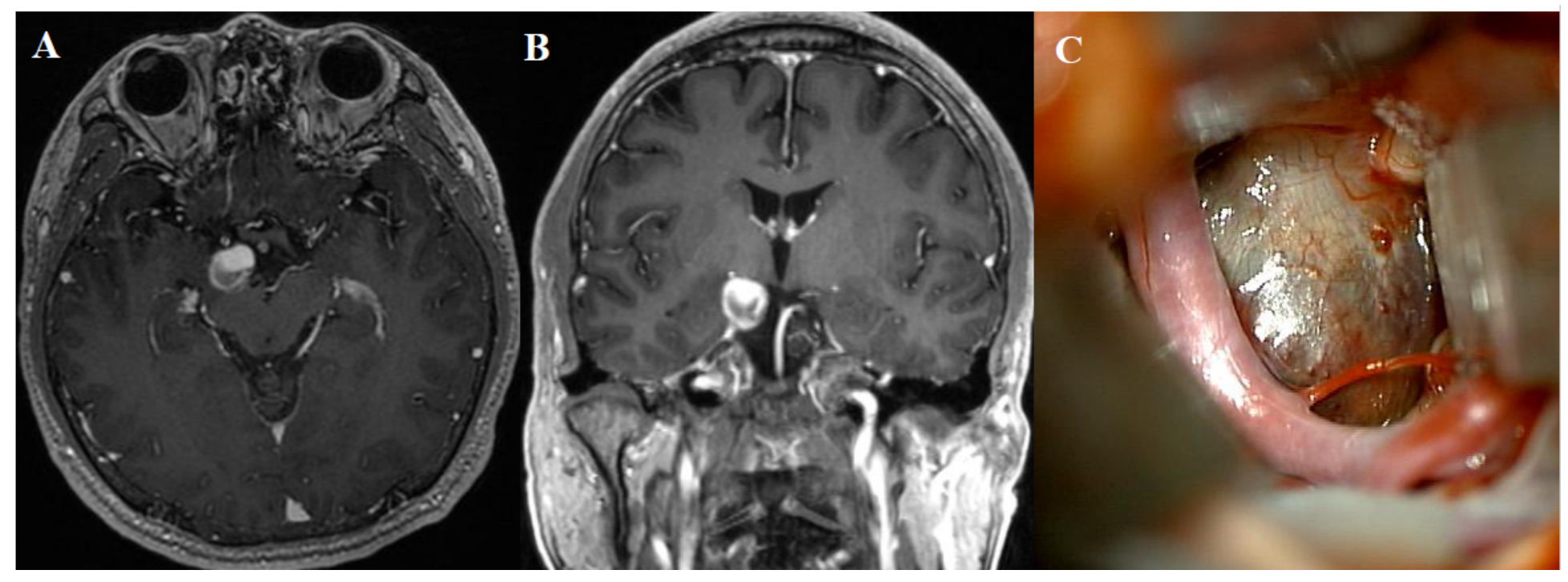

\section{Figure 2}

A, B: Axial and coronal image of T1-weighted brain magnetic resonance imaging with gadolinium contrast shows a well-enhanced mass in the right-sided ambient and crural cisternal space. A central hemorrhagic area is seen inside the tumor. C: Intraoperative view of the mass, exposed though a right-sided modified lateral supraorbital approach. 


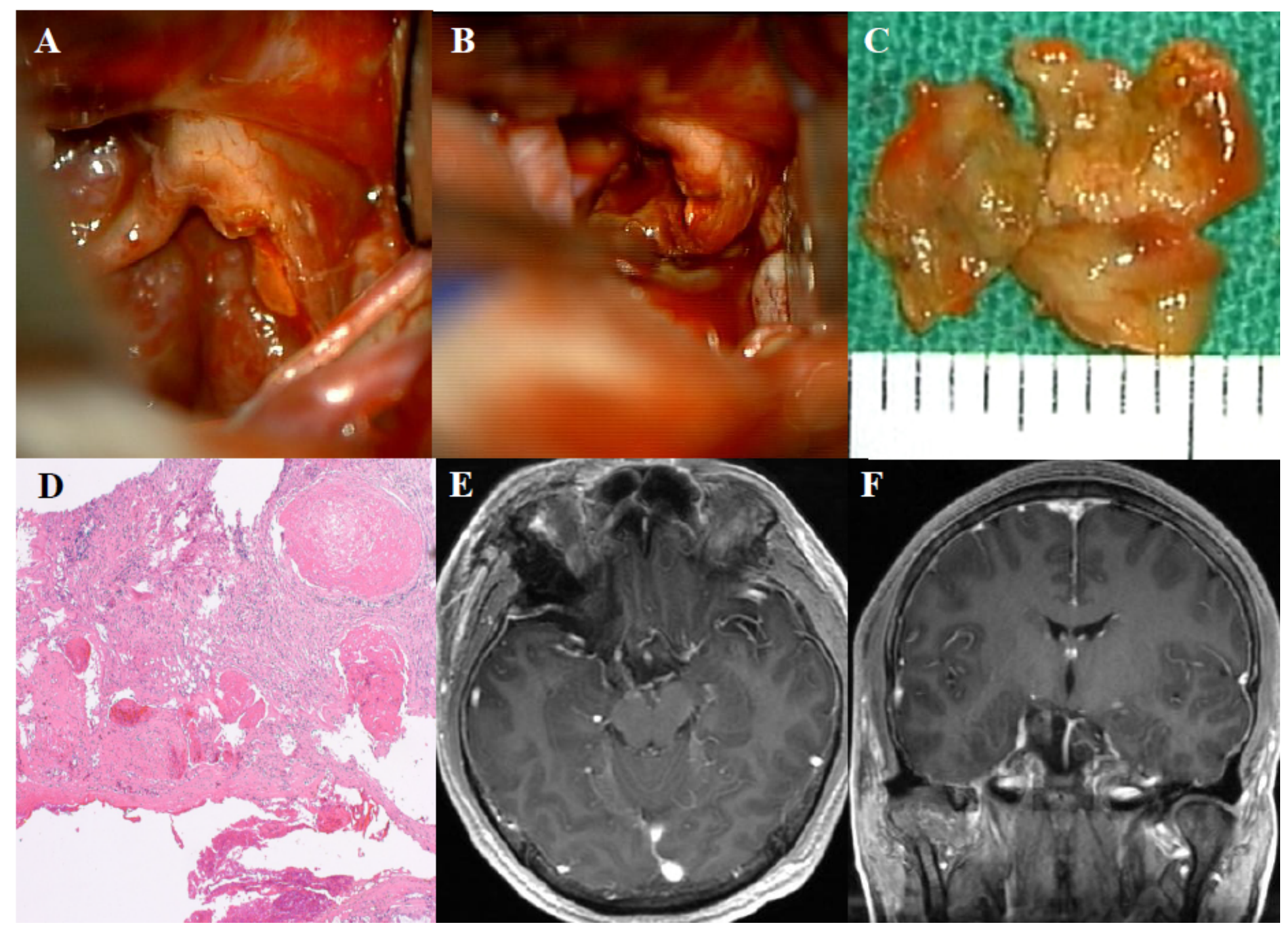

Figure 3

A, B: Intraoperative view after removal of the mass. The residual lesion is present, and CN III continuity is preserved. C: Gross examination showed a vascular mass containing vessel and hematoma. D: Histopathological examination of hematoxylin-eosin stained surgical specimen (X40) shows a typical cavernous malformation with endothelium-lined, sinusoidal cavities without other features of normal blood vessels, such as muscular or adventitial layer. E, F: Postoperative T1-weighted MRI with contrast showed a small, enhanced remnant mass on axial and coronal image.

\section{Supplementary Files}

This is a list of supplementary files associated with this preprint. Click to download.

- Videoclip.mpg 